\title{
The Representation of Psychomotor Domain in English Textbooks for Senior High School Grade X
}

\author{
Nursyahrifa $^{1}$, Mukhaiyar $^{2}$, and Jufrizal ${ }^{3}$ \\ ${ }^{1}$ Universitas Negeri Padang, Padang, Indonesia, $\triangle$ (email), nursyahrifanursyahrifa@gmail.com. \\ ${ }^{2}$ Universitas Negeri Padang, Padang, Indonesia, $\triangle$ (email), mukhaiyar@gmail.com \\ ${ }^{3}$ Universitas Negeri Padang, Padang, Indonesia, $ه$ (email), juf_ely@yahoo.com
}

\begin{abstract}
This study was conducted to evaluate the revised edition of two English textbooks entitled Bahasa Inggris and Pathway to English for senior high school grade $\mathrm{x}$. The aim is to evaluate the extent to which these textbooks offer learning that promotes students' psychomotor skill. Basic competencies in psychomotor domain of curriculum 2013 were used and adapted to evaluate the textbooks. The evaluation shows that the textbooks receive good score in some evaluation items. The two textbooks receive 19 out of a maximum of 24 . The textbooks' authors have tried to provide opportunity for students to improve their abstract and concrete skills since the materials, tasks, and activities in some units of the textbooks suit the expectation of psychomotor domain stated in the basic competencies of curriculum 2013 revised version. Nonetheless, some units require additional instructions that give more opportunities for students to enhance their psychomotor skill.
\end{abstract}

\section{Keywords: English Textbooks, Textbook Evaluation, Psychomotor Domain}

\section{INTRODUCTION}

The suitability of an English textbook with the curriculum is one of the important things to be considered before selecting a textbook as a learning source in the classroom. This is supported by Garinger (2002) who puts "matching the textbook to the program and the course" as one of the steps in textbook selection. Based on the statement, it seems that textbook evaluation is necessary to be conducted. This is important to select an appropriate textbook that can help teachers and students achieve the goal of curriculum.

The evaluations in terms of the suitability of the curriculum with the textbooks have been conducted by a number or researchers. First, Arono and Syafrina (2017) investigated three English textbooks in terms of contents, presentation, language, and graphic. The analysis in terms of contents found that Pathway to English published by Erlangga and Bahasa Inggris published by Kemdikbud were categorized good since most of the contents are suitable with core competence and basic competence of curriculum 2013. On the other hand, the textbook published by Yrama Widya was categorized fair. In another study, Margana and Widyantoro (2016) investigated previous publication of Bahasa Inggris published by Kemdikbud for grade ten of the first semester. The evaluation focuses on six aspects that consist of the suitability of core and basic competencies in reference to the content, the organization of English textbook and language skill areas, the contextualization of tasks, critical thinking skill enhancement, the integration of culture, and learner characteristic accommodation.
Regarding the suitability of core and basic competencies with the content, they found that Bahasa Inggris textbook was designed based on core competence and basic competence. Those are demonstrated in the objectives and the activities provided in the textbook. Nimasari (2016) furthermore evaluated the extent to which the 2013 curriculum-based textbook accomplishes pedagogical aspects: methodology, content coverage, material completeness, presentation, design, and learner's factors. The findings in terms of methodology aspect show that Bahasa Inggris textbook has put core competencies and basic competencies in the objectives. However, spiritual and social aspects receive little attention since the skills were integrated with other competencies. Furthermore, she also found that the materials in Bahasa Inggris textbook have followed the syllabus of curriculum 2013 appropriately. With regard to scientific approach, she found that the stages of scientific approach were not stated in specific but those are presented through activities provided. In addition, observing stage gets less attention since the textbook has no contents for listening activities.

The findings of the studies above show that the textbooks evaluated have not completely followed the requirements of curriculum 2013. For this reason, following the discussion in previous studies especially on the revised version of the English textbooks can be beneficial for the consumers of English textbooks to get information regarding the strengths and weaknesses of the textbooks. Therefore, this study reports the evaluation on the two English textbooks revised edition about the extent to which the textbooks provide learning to promote 
students' psychomotor skill on the basis of core competence and basic competencies of curriculum 2013 in psychomotor domain. For Bahasa Inggris textbook, we did not only evaluate the student's book but also the teacher's book as comparison to see how far Bahasa Inggris textbook helps students develop their psychomotor skill. This study is expected to verify and strengthen the result of the existing research as well as complete or provide new insights that may not cover yet in earlier studies.

To evaluate the English textbooks, the researchers used basic competencies of English subject that focus on psychomotor domain. Basic competencies in psychomotor domain requires students to compose spoken and written texts that consists of interpersonal text, transactional texts, functional text, and essay texts such as recount, descriptive, and narrative. (Kemdikbud, 2016). It also expects students to comprehend functional text, essay texts, and songs (Kemdikbud, 2016). Putra (2014, p.70) claims that curriculum 2013 concentrates to develop students' ability to produce oral and written texts. Psychomotor domain of Kurikulum 2013 utilizes the gradation proposed by Dyer and Dave (Kemdikbud, 2016). It is divided into abstract skill and concrete skill. Abstract skill refers to gradation of Dyer that is arranged as mengamati (observing), menanya (questioning), mencoba (experimenting), menalar (associating), menyaji (communicating), and mencipta (creating) (Kemdikbud, 2016, p. 5). The learning steps and the activities can be seen more detail below.

Table 1. The Relation between Learning Steps and Activities in Curriculum 2013

\begin{tabular}{|c|c|}
\hline STEPS OF LEARNING & LEARNING ACTIVITIES \\
\hline $\begin{array}{l}\text { Mengamati(Observing } \\
\text { ) }\end{array}$ & $\begin{array}{l}\text { - Reading, listening, observing (with } \\
\text { or without tools) }\end{array}$ \\
\hline $\begin{array}{l}\text { Menanya } \\
\text { (questioning) }\end{array}$ & $\begin{array}{l}\text { - Asking questions in order to get } \\
\text { better understanding related to } \\
\text { what has been observed or to get } \\
\text { additional information. (Factual to } \\
\text { hypothetical questions). }\end{array}$ \\
\hline $\begin{array}{l}\text { Mengumpulkaninfor } \\
\text { masi(experimenting) }\end{array}$ & 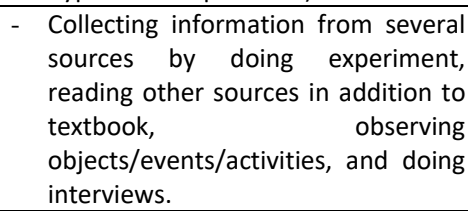 \\
\hline $\begin{array}{l}\text { Mengolahinformasi }(a \\
\text { ssociating) }\end{array}$ & $\begin{array}{l}\text { - Processing the information collected } \\
\text { based on the result of observation } \\
\text { or experiment. } \\
\text { - It begins from the processing } \\
\text { information that increases the } \\
\text { breadth and depth to the processing } \\
\text { information that tends to find } \\
\text { solution from various sources having } \\
\text { different and contradictory opinion. }\end{array}$ \\
\hline $\begin{array}{l}\text { Mengkomunikasikan } \\
\text { (Communicating) }\end{array}$ & $\begin{array}{l}\text { - Presenting the observation result } \\
\text { orally, in written form or other } \\
\text { media. }\end{array}$ \\
\hline
\end{tabular}

Source: Regulation of the Minister of Education and Culture number 81 A of 2013 concerning Curriculum Implementation
Based on the table above, it can be understood that psychomotor domain attracts students to learn communicatively, independently, and collaboratively starting from observing, asking questions related to what has been observed, collecting and processing the information as well as presenting the observation result. Furthermore, psychomotor domain of curriculum 2013 in concrete skill refers to gradation proposed by Dave (Kemdikbud, 2016, p. 5). It consists of imitation, manipulation, precision, articulation, and naturalization. Tenth grade students are expected to achieve the two levels of gradation, namely imitation and manipulation (Kemdikbud, 2016, p. 16). The explanations of each level can be seen in the table below.

Table 2. Gradation of Psychomotor Domain from Dave (1967)

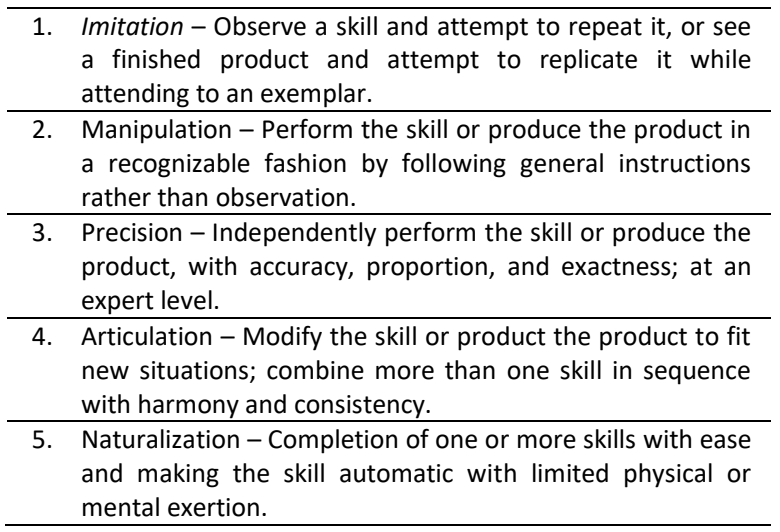

(Cited in Huitt, 2003)

\section{METHOD}

This study employed a descriptive qualitative study. The English textbooks for the tenth grade published by Ministry of Education and Culture and Erlangga were selected as the sources of data. The textbooks are the revised edition based on revised version of curriculum 2013. Bahasa Inggris is written by Utami Widiati, Zuliati Rohmah, and Furaidah and published by Ministry of Education and Culture in 2017. It consists of teacher's book and student's book. The student's book contains 220 pages divided into 15 units. In addition, the teacher's book contains 202 pages divided into 15 units.

Every chapter in the textbook has the organization that consists of warmer, vocabulary builder, pronunciation practice, reading, vocabulary exercises, grammar review, speaking, writing, and reflection at the end of each chapter. The topics in each lesson consist of talking about self, congratulating and complimenting others, expressing intention, which one is your best getaway?, Lets Visit Niagara Falls, Giving Announcement, My Idol, The Battle Of Surabaya, B.J. Habibie, Cut Nyak Dien, Issumboshi, Malin Kundang, Strong Wind, and You've Got A Friend. During the evaluation on the student's book, the researchers also did an evaluation on the teacher's book since it can give more complete depictions. Not all chapters in Bahasa Inggris textbook 
were evaluated since there are additional topics in the textbook which are not included in the basic competencies of curriculum 2013 revised edition.

Likewise, Pathway to English written by Th. M. Sudarwati and Eudia Grace and published by Erlangga in 2016 is the revised edition based on Kurikulum 2013 yang disempurnakan. It contains 206 pages divided into ten units. The structure or organization in every unit consists of share your experience, spoken texts, cultural awareness, written texts, grammar in action, and self reflection at the end of each chapter. The topics in each lesson consist of Hi, My Name Is, Well Done!, Congratulation!, I will Improve My English, It's a Wonderful Place, Listen to the School Announcement, I've Been There, Past Echoes of the Nations, A Long Time Ago, and Sing Your Heart Out!.

To answer the research question, the researchers administered a table of textbook evaluation criteria that was adapted based on basic competencies of curriculum 2013 in psychomotor domain. To obtain the validity of the items, the researcher validated the instrument to the three experts in the area of English Language Teaching and Research Methodology. To evaluate the textbook, the researchers read every item in the table evaluation, observed and reviewed each unit in the textbooks, took some important notes, and repeated the observations in order to generate the correct data. After doing deep review, the researchers put a tick in three possible answer choices provided, such as "good", "satisfactory", and "poor". "A comparative weight is assigned to the relative realization of each actual criterion in the textbook under scrutiny: a perfect match between the ideal defined criterion and its actual realization in the textbook receiving two, a total lack a score of zero, and any inadequate match a score of one" (Anshari and Babaii, 2002; AbdelWahab, 2013, p. $63)$.

\section{RESULT AND DISCUSSION}

This part displays the evaluation of two English textbooks along with the samples of activities taken from textbook 1 and textbook 2 as shown in Table 3 . In directing students to achieve core competence and basic competencies in psychomotor domain, some units in textbook 1 and 2 have tried to direct students to compose spoken and written texts. This finding is in agreement with the statement asserted by Putra (2014, p 70) that the focus of curriculum 2013 is to develop students' ability to produce oral and written text. For example, there are several instructions in chapter 1 of textbook 1 directing students to compose spoken and written texts about introducing and mentioning identity. On page 12, students are instructed to get to know their friends by asking some questions related to identities. Following this, there is a form about personal identities in the textbook that has to be filled by them. On page 17, students are asked to write a similar conversation about personal identity based on the example given. On page 23 , they are asked to introduce themselves individually in front of the class by using one of the monologues provided. In written production, they
Table 3. Results of Evaluation of Two English Textbooks in Psychomotor Domain

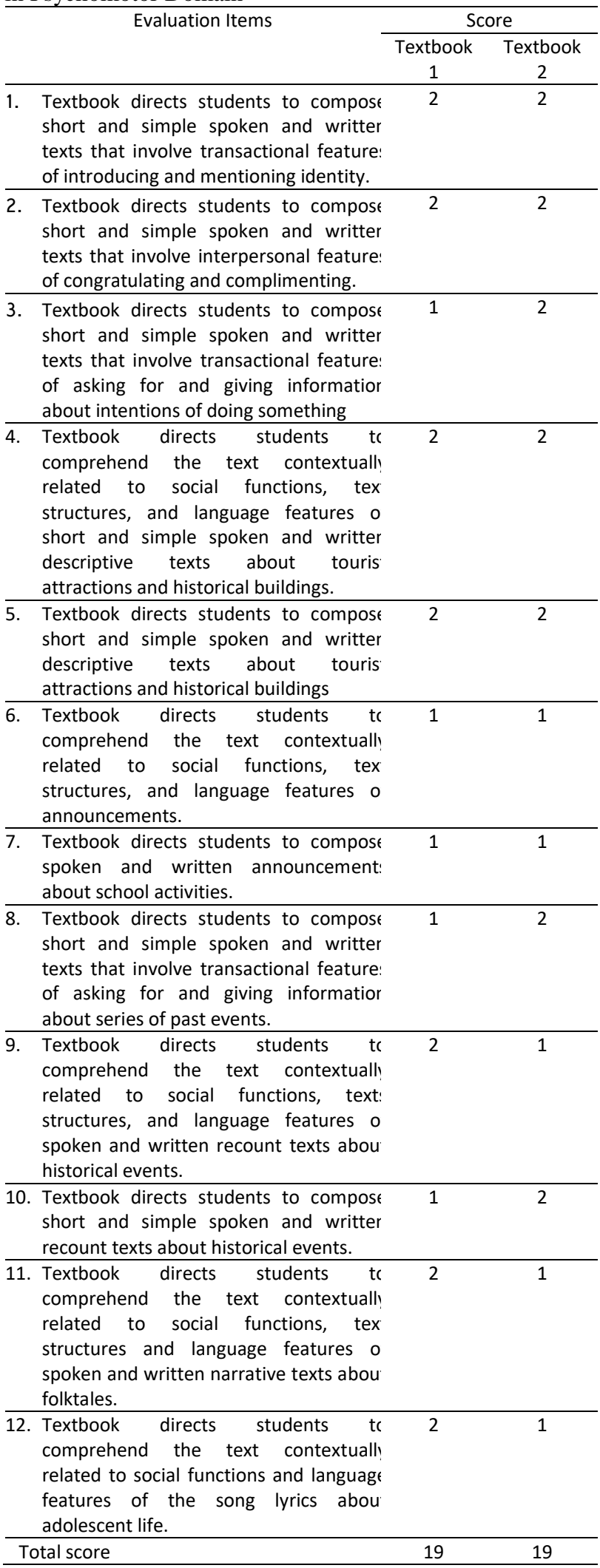

Note: Textbook 1 refers to Pathway to English and textbook 2 refers to Bahasa Inggris 
are asked to write a reply to Suzan's letter provided in the textbook.

Textbook 2 also includes several instructions that assign students to compose spoken and written texts. On page 17 for example, students are instructed to practice a dialogue between Edo and Slamet who introduce themselves to each other. After that, they are instructed to imagine that they are all invited to a party. They are then asked to talk to each other and introduce themselves by telling about their families, their professions, and their hobbies. The instruction is followed by assigning them to introduce their friends to at least two people. In written personal information, they are asked to reply the email that have been read and discussed previously. In their composition, they have to consider about the text structures and grammatical features. On page 9, teacher's book suggests that teachers should discuss the questions in the student's book to help students write the reply of a letter in chronological order.

Similarly, Arono and Syafrina (2017) in their study found that students have been given well opportunities by Pathway to English and Bahasa Inggris to improve their reading, writing, listening, and speaking skills through various functional texts and monologues. They further contend that "it can be seen in the integration of the four skills in enabling learners to comprehend and produce those functional texts both oral and written". In one side, the finding of the present study is in agreement with Arono and Syafrinas' finding since these two textbooks have tried to provide opportunity for students to compose spoken and written texts. Contrarily, we found more items receive "satisfactory" score in Pathway to English revised edition. Therefore, more instructions and activities need to be added in order to give more opportunity for students to produce spoken and written texts.

In addition, to direct students to comprehend the meaning of the texts, most of units in textbook 1 have given several instructions assigning students to search texts, answer some questions and have discussion with their friends; it is also followed by requiring them to present the result of their discussion in front of other members. For example, on page $82,84,91,92$, the textbook presents descriptive texts, such as Taman Mini Indonesia Indah, Purna Bakti Pertiwi Museum, Singapore, London, and Semarang City. Students are then asked to answer comprehension questions provided. On page 105, they are required to find information about their favorite town/city and they have to answer the following questions: 1) Where is the town/city located? 2) How large is the area? 3) What is the population? 3) What ethnicities live there? 4) What are the popular landmarks that the town/city is famous for? On page 106, students are given the text entitled The Borobudur Temple. In further, they are required to answer questions in pairs and present the result of their discussion in front of the class. These instructions enable them to process and present their analysis. These findings are in line with basic competencies of curriculum 2013 revised edition in psychomotor domain stated in regulation of the Minister of
Education and Culture number 24 of 2016 appendix 47 and the learning steps of curriculum 2013 stated in regulation of the Minister of Education and Culture number 81 A of 2013.

Subsequently, in positive notes, some units in textbook 2 have also enabled students to comprehend the texts. It has included comprehension questions for students to be discussed with their teacher and friends. On page 53 and 58, it presents descriptive texts about Tanjung Puting National Park and Taj Mahal. Students are then instructed to answer the questions related to social functions, text structures and language features of the texts as well as the questions related to the information given in text. The procedures for the reading task exist in the teacher's book on page 41. The textbook recommends that students sit in a group of four and discuss the answer of the questions. Each student in a group is given a number and they are instructed to answer the question based on their own number. To allow students to share their ideas, teacher's book suggests that teacher should ask each student in each group who has the same number to share their ideas and ask whether they agree with the answer given from the member of other groups. Therefore, this activity enables students to share and present their analysis.

These findings are in agreement with core and basic competencies of curriculum 2013 revised version in psychomotor domain stated in regulation of the Minister of Education and Culture number 24 of 2016 appendix 47 and the learning steps of curriculum 2013 stated in regulation of the Minister of Education and Culture number $81 \mathrm{~A}$ of 2013.These findings are supported by Margana \& Widyantoro (2016) who found that most of the contents in Bahasa Inggris textbook meet core and basic competencies of curriculum 2013 since the English textbook was primarily designed based on core and basic competence. $\mathrm{He}$ further asserts that those competencies are demonstrated in the objectives and the series of tasks provided in the textbook. It is also supported by Nimasari (2016) claiming that "BI textbook had included both core and basic competence in the objective although the spiritual and social competence was less developed in the material". She further states that "in the suitability of the syllabus, it was found that BI textbook was very appropriate with the requirements of the syllabus".

It is true that Bahasa Inggris textbook is developed on the basis of core competencies and basic competencies of curriculum 2013. The objectives in each chapter of the revised edition of teacher's book were also found very suitable with the objectives in the curriculum. Nonetheless, some units, specifically the contents for psychomotor skill, require improvement in order to give more opportunity for students to develop their abstract skill. This is because some evaluation items in the table receive "satisfactory" score. In addition, Nimasari's study (2016) found that observing stage gets less attention since it does not have contents for listening. Therefore, it can be concluded that the new publication of English textbook still have drawbacks. The revision would include adding more activities in abstract skill such as mengamati (observing), menanya (questioning), mencoba 
(experimenting), menalar (associating), and menyaji (communicating). To overcome the drawbacks in each textbook, the teacher can modify the instructions and activities in each unit of the English textbooks. Teachers can also use other learning materials or combine these two textbooks since they have strong and weak points each other.

\section{CONCLUSION}

This study was conducted to evaluate the representation of psychomotor domain in the English textbooks. The evaluation reveals that the two textbooks have received good score in some evaluation items. However, textbook 1 still obtains satisfactory score in 5 items (3, 6, 7, 8, and 10) and textbook 2 also gains satisfactory score in five items $(6,7,9,11$, and 12). Based on the findings, the textbooks need revisions. Revisions would include providing additional instructions or more opportunities for students to improve their abstract and concrete skills.

\section{REFERENCES}

[1] AbdelWahab, M. M. (2013). Developing an English language textbook evaluative checklist. IOSR Journal of Research \& Method in Education (IOSR-JRME), 1(30), 55-70. https://pdfs.semanticscholar.org/a321/8ce90166e4 45f9ace1389fb7f0f58ec19319.pdf

[2] Ansary, H. \& Babaii, E. (2002). Universal characteristics of EFL/ESL textbooks: A step towards systematic textbook evaluation. The Internet TESL Journal, 8(2), Retrieved from http://iteslj.org/Articles/Ansary-Textbooks/

[3] Arono., \& Syafrina, E. (2017). Features of English textbooks for the first year of senior high school implementing the 2013-curriculum. Journal of Applied Linguistics and Literature, 2 (2), 1-13. https://doi.org/10.33369/joall.v2i2.5950

[4] Garinger, D. (2002). Textbook selection for the ESL classroom. ERIC Clearinghouse on Languages and Linguistics. Washington, DC. Retrieved from http://prodibing.fkip.unsri.ac.id/userfiles/text $\% 20 \mathrm{~b}$ ook\%20selction.pdf

[5] Huitt, W. (2003). The psychomotor domain. Educational Psychology Interactive. Valdosta, GA: Valdosta State University. Retrieved from http://www.edpsycinteractive.org/topics/behavior/ psymtr.html

[6] Kemdikbud. (2013). Peraturan Menteri Pendidikan dan Kebudayaan No. 81 A tentang implementasi Kurikulum 2013. Jakarta: Author

[7] Kemdikbud. (2016). Materi pelatihan dan pendampingan implementasi kurikulum 2013 SMK. Jakarta: Author.
[8] Kemdikbud. (2016). Peraturan Menteri Pendidikan dan Kebudayaan No. 24 lampiran 47 tahun 2016. Jakarta: Author.

[9] Margana., \& Widyantoro, A. (2016). An evaluation of English textbook used at senior and vocational high schools oriented to curriculum 2013. Researchers World-Journal of Arts, Science And Commerce, 4(1),108-119. http://dx.doi.org/10.18843/rwjasc/v7i4(1)/13

[10] Nimasari, E. P. (2016). Evaluating an EFL textbook: To what extent does the 2013 curriculum-based textbook accomplish pedagogical aspects? Prosiding ICTTE FKIP UNS, 1(1), 269-278. Retrieved from http://jurnal.fkip.uns.ac.id/index.php/ictte/article/v iew/7630/5471

[11] Putra, K. A. (2014). The implication of curriculum renewal on ELT in Indonesia. PAROLE: Journal of Linguistics and Education, 4(11), 63-75. https://doi.org/10.14710/parole.v4i1 April.63-75

[12] Sudarwati, Th. M., \& Grace, E. (2016). Pathway to English for SMA/MA Grade X. Jakarta: Erlangga.

[13] Widiati, U., Rohmah, Z., \& Furaidah. (2017). Bahasa Inggris (Buku Guru). Jakarta: Kemendikbud.

[14] Widiati, U., Rohmah, Z., \& Furaidah. (2017). Bahasa Inggris. Jakarta: Kemendikbud. 